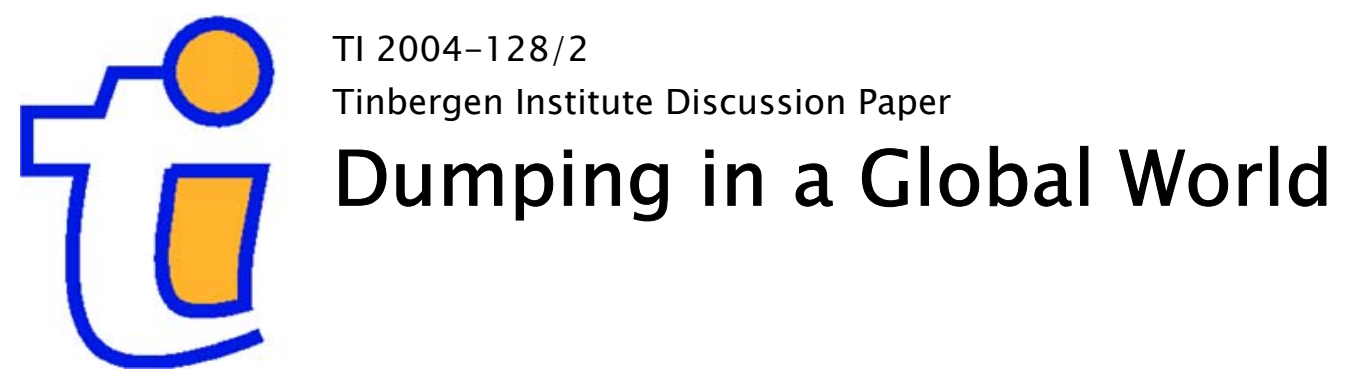

José Luis Moraga-González Jean-Marie Viaene

Faculty of Economics, Erasmus Universiteit Rotterdam, Tinbergen Institute, and CESifo. 
Tinbergen Institute

The Tinbergen Institute is the institute for economic research of the Erasmus Universiteit Rotterdam, Universiteit van Amsterdam, and Vrije Universiteit Amsterdam.

Tinbergen Institute Amsterdam

Roetersstraat 31

1018 WB Amsterdam

The Netherlands

Tel.: $\quad+31(0) 205513500$

Fax: $\quad+31(0) 205513555$

Tinbergen Institute Rotterdam

Burg. Oudlaan 50

3062 PA Amsterdam

The Netherlands

Tel.: $\quad+31(0) 104088900$

Fax: $\quad+31(0) 104089031$

Please send questions and/or remarks of nonscientific nature to driessen@tinbergen.nl.

Most TI discussion papers can be downloaded at http://www.tinbergen.nl. 


\title{
Dumping in a Global World: Why Product Quality Matters*
}

\author{
José Luis Moraga-González and Jean-Marie Viaene ${ }^{\dagger}$ \\ Erasmus University Rotterdam, Tinbergen Institute and CESifo
}

May 2004

\begin{abstract}
Anti-dumping actions are now the trade policy of choice of developing and transition economies. To understand why these economies have increasingly applied anti-dumping laws, we build a simple theoretical model of vertical intra-industry trade and investigate the strategic incentives of exporting firms to undertake dumping. We show that the definition of dumping matters. Based on a comparison of low-quality and high-quality prices, only unilateral dumping by the low-quality firm obtains. By contrast, the standard WTO definition leads to either reciprocal or unilateral dumping depending on differences in incomes and on the height of tariff protection and of the exchange rate depreciations.
\end{abstract}

JEL classification: F12, F13, P31

Key words: Dumping, Exchange Rate, Injury, Product Quality, Tariffs.

\section{Introduction}

Current anti-dumping activities are very different from those observed in the past 100 years of antidumping legislation. While anti-dumping actions were only used by major industrial countries less than a decade ago, they are now the trade policy of choice of developing and transition economies

*We thank Alan Deardorff, Robert Stern and the participants of the International Workshop "Centennial of AntiDumping Legislation and Implementation" held at the University of Michigan for helpful comments and suggestions. This article surveys recent results on dumping obtained from trade models with vertically differentiated products (see Moraga-Gonzlez and Viaene (2004a, 2004b) for technical details). This paper was written while Viaene visited the Department of Economics of the University of Michigan, whose hospitality and financial support are gratefully acknowledged. He also thanks the Center for European Studies of the University of Michigan and the Royal Netherlands Academy of Arts and Sciences for financial support.

${ }^{\dagger}$ Address for correspondence: Erasmus University Rotterdam, Department of Economics, Burg. Oudlaan 50, 3062

PA Rotterdam, The Netherlands. E-mails: <moraga@few.eur.nl> and < viaene@few.eur.nl> 
as well. Most anti-dumping investigations against Member States of the European Community currently emanate from countries like China, Czech Republic, Bulgaria, India, Russia, etc. On a worldwide basis, India has since 2001 overtaken the US in terms of initiations of new anti-dumping cases. In terms of cases per dollar of imports, India's intensity of anti-dumping use is seven times the U.S. figure, though this is less than Argentina's, whose intensity is 20 times the U.S. figure (Finger, Ng and Wangchuk, 2000).

The publication of the Boskin report on the upward bias of U.S. inflation (Boskin et al., 1996) has led to renewed research on the impact of product quality on prices and volumes of transactions. Differences in product quality are particularly important in international trade where firms in developing and transition economies have different concerns for quality standards. It is the key point of Greenaway et al. (1995) who show that intra-industry trade characterized by different levels of quality is a significant proportion of trade. Central to the research agenda is the issue that when product quality matters, the response of firms to government policies, and the effects of such policies on social welfare, can differ markedly from that of received theory. In this regard, the aim of the paper is to examine the strategic incentives of oligopolistic exporting firms to undertake dumping and to understand why developing and transition economies have increasingly applied anti-dumping laws.

In recent years, a number of theoretical models have been developed to examine the export behavior of firms under different market structures. The survey by Blonigen and Prusa (2003) thoroughly reviews the existing theoretical and empirical work, and describes the various market outcomes of resulting anti-dumping actions. The existing literature largely discusses outcomes of anti-dumping laws in developed countries. However, dumping by Western firms is also observed in industries of developing and transition economies whose economic characteristics are different.

Though developing and transition economies differ in many respects, there are a number of common economic characteristics that have inspired our framework of analysis:

- A limited concern for quality standards has often driven firms in transition economies to supply goods whose quality is inferior to that of Western firms. The data suggest that average unit values of imports over exports vary significantly across transition economies. For example, Lankhuizen (2000) finds that there is a quality advantage of imports over exports for the majority of sectors of the Baltic countries. Moreover, average export unit values for the Czech Republic, Hungary, Poland and Slovenia are generally lower than what is observed for Mediterranean countries (Aturupane et al., 1999). 
- Though quality differentials are normally associated with highly technological and industrialized goods, they also exist among seemingly identical goods like agricultural products, freedom from disease being then one important aspect of quality.

- It is common that anti-dumping cases concern two players, a local producer and a foreign exporter. The presence of institutional entry barriers implies that industries in many transition and developing economies are highly concentrated and in many cases monopolized.

The determination of dumping relies on three main principles. First, domestic and export goods must be "like" products: this means alike in all respects or having characteristics closely resembling those of the product under consideration. In practise, though quality differentiation is discussed in investigations, it does not often lead to a classification of low-quality and high-quality goods in different industries. Second, a local firm may petition the government for relief if dumped imports materially injure the local industry. In the discussion of market equilibrium obtained in this paper, we compute market shares and find that they are large enough to justify injury. Third, a product is to be considered as being dumped if its export price to a particular country is less than a "normal value". The latter is a crucial concept and we show that using different proxies for the normal value leads to distinct outcomes regarding dumping.

The paper is organized as follows. In section 2, we lay out the general structure of the model and describe the extensive form of the game. In section 3, we obtain the conditions for dumping. In section 4 we derive the market equilibrium and determine whether there is injury to the local industry. In section 5 we outline the effects of changes in the exchange rate on dumping. We conclude in section 6 . The appendix contains a glossary of symbols.

\section{The Model}

We analyze dumping in the context of markets in two countries, which we shall call "domestic" and "foreign", the latter denoted by "*". The domestic country is meant to represent a developing or transition economy; the foreign country is a developed economy. Suppose that a population of measure 1 lives at home and that preferences of domestic consumer $\theta$ are given by the quasi-linear utility function:

$$
U=\left\{\begin{array}{cc}
\theta q-p & \text { if she buys a unit of a good of quality } q \text { at price } p \\
0 & \text { otherwise }
\end{array}\right.
$$


Consumers buy at most one unit. We assume the consumer-specific quality taste parameter $\theta$ is uniformly distributed over the set $[0, \bar{\theta}], \bar{\theta}>0$.

Preferences of foreign consumers are also given by (1) but we allow for a population of measure $m^{*} \geq 1$ to live abroad and for the foreign taste parameters $\theta^{*}$ to be uniformly distributed over the set $\left[0, \lambda^{*} \bar{\theta}\right]$, with $\lambda^{*}>1$. Tirole (1988) shows that $\theta$ in (1) is the inverse of the marginal utility of income. As $\theta^{*}$ is distributed over a larger set than $\theta$, higher incomes are observed in the foreign country. In our framework, $\lambda^{*}$ is therefore a measure of the difference in incomes across countries.

We assume there are two firms, one in each country. Let $q$ and $q_{\ell}$ denote the quality produced by the home firm to be sold at home and abroad respectively. Likewise, let $q^{*}$ and $q_{h}^{*}$ denote the quality produced by the foreign firm to be sold locally and abroad respectively. Following Eaton and Schmitt (1994), we introduce production flexibility in this model by assuming that firms first develop one basic product and then can produce downgrades of these basic products at no cost. As firms incur fixed costs of quality development, flexibility amounts to assuming cost functions of the form: $C\left(q, q_{\ell}\right)=c \max \left\{q, q_{\ell}\right\}^{2} / 2$ and $C^{*}\left(q^{*}, q_{h}^{*}\right)=c^{*} \max \left\{q^{*}, q_{h}^{*}\right\}^{2} / 2$. As $c$ and $c^{*}$ are expressed in different currencies, let us introduce $e$, the forward exchange rate given to the firms defined as the domestic currency price of foreign currency. We assume $c>e c^{*}$, that is, the foreign firm is more efficient than the domestic firm in producing any quality level. Marginal costs are set equal to zero.

Given these assumptions, Moraga-González and Viaene (2004) show that it is optimal for the firms to sell the same level of quality abroad and at home, i.e., $q^{*}=q_{h}^{*}$ and $q=q_{l}$, with $q_{h}^{*}>q_{l}$. A second useful result is that, because it is more efficient, the foreign firm will manufacture the high-quality product in equilibrium, while the domestic firm will produce the low-quality variant (see also Motta et al., 1997). On the basis of these results, in what follows, we shall derive profits functions with two qualities, low quality $q_{\ell}$ and high quality $q_{h}^{*}$. Define first the corresponding prices charged in the domestic economy by $p$ and $p_{h}^{*}$, with $p_{h}^{*}>p$. Domestic demands are derived as in Moraga-González and Viaene (2004):

$$
D_{\ell}(.)=\frac{p_{h}^{*}-p}{\bar{\theta}\left(q_{h}^{*}-q_{\ell}\right)}-\frac{p}{\bar{\theta} q_{l}}, D_{h}(.)=1-\frac{p_{h}^{*}-p}{\bar{\theta}\left(q_{h}^{*}-q_{\ell}\right)}
$$

Domestic demand for low quality $D_{l}$ is satisfied by the local firm at price $p$ and domestic demand for high quality $D_{h}$ is met by imports from the foreign firm at the price $p_{h}^{*}$. Foreign demands for both variants are obtained in a similar way. First denote $p_{\ell}$ and $p^{*}$ as the price of low quality and of high quality charged in the foreign market, respectively and recall that the foreign preference 
parameter $\theta^{*}$ is uniformly distributed on $\left[0, \lambda^{*} \bar{\theta}\right]$, then:

$$
D_{\ell}^{*}=m^{*}\left[\frac{p^{*}-p_{\ell}}{\lambda^{*} \bar{\theta}\left(q_{h}^{*}-q_{\ell}\right)}-\frac{p_{\ell}}{\lambda^{*} \bar{\theta} q_{\ell}}\right], D_{h}^{*}=m^{*}\left[1-\frac{p^{*}-p_{\ell}}{\lambda^{*} \bar{\theta}\left(q_{h}^{*}-q_{\ell}\right)}\right]
$$

Foreign demand for low quality $D_{\ell}^{*}$ is met by imports from the domestic firm while foreign demand for high quality $D_{h}^{*}$ is satisfied by the foreign firm.

We study a two-stage complete information game. Parameters given to the firms are the exchange rate $e$ and the domestic and foreign ad valorem tariff rates on imports $t$ and $t^{*}$ respectively. In the first stage, firms select simultaneously their quality levels and incur the fixed costs of quality development. In the second stage, firms select their prices. We solve the model by backward induction.

\section{Conditions for Dumping}

We now proceed to derive the equilibrium outcome in stage 2 taking $(i)$ any profile of quality choices $\left(q_{\ell}, q_{h}^{*}\right),(i i)$ trade policies $\left(t, t^{*}\right)$ and $(i i i)$ the exchange rate $e$ as given. Using the derived domestic demands in (2), foreign demands in (3) and cost functions, the problem of the domestic firm is to select prices $p$ and $p_{\ell}$ so as to maximize the international profit:

$$
\pi=p D_{\ell}+e p_{\ell}\left(1-t^{*}\right) D_{\ell}^{*}-\frac{c}{2} q_{\ell}^{2}
$$

where $p_{\ell}\left(1-t^{*}\right)$ is the international price of low-quality exports and where the exchange rate converts this price into domestic currency. Likewise, the decision problem of the foreign firm is to find $p^{*}$ and $p_{h}^{*}$ so as to maximize the following profit function:

$$
\pi^{*}=p^{*} D_{h}^{*}+\frac{p_{h}^{*}(1-t)}{e} D_{h}-\frac{c^{*}}{2}\left(q_{h}^{*}\right)^{2},
$$

where $p_{h}^{*}(1-t)$ is the international price of foreign firm's high-quality exports and the exchange rate converts foreign export receipts in foreign currency. Taking the first order conditions of (4) and (5) with respect to prices, we obtain the best-response functions in prices. These are represented in Figure 1 for the domestic market. The equilibrium prices of the subgame are given by point $E$ where the best-response functions cross. 


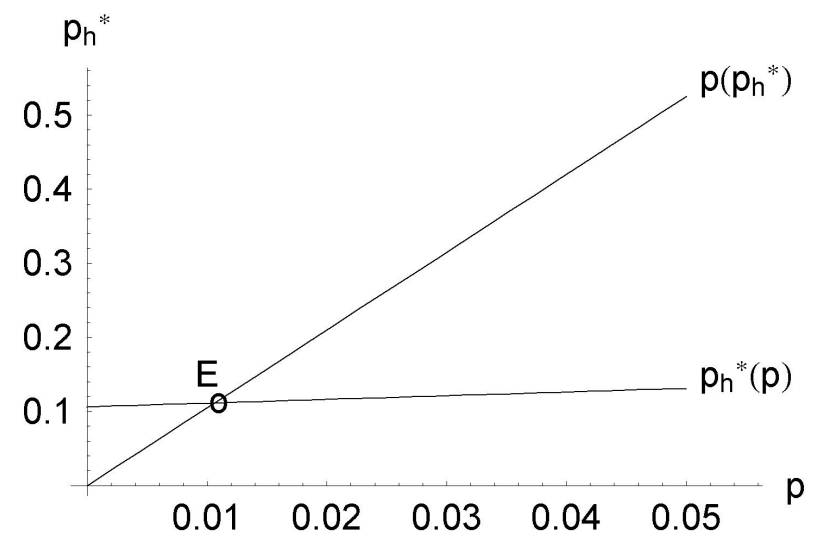

Figure 1: Equilibrium in prices in the domestic market.

If we define $\mu$ as the quality gap between firms' product quality, $\mu^{*}=q_{h}^{*} / q_{\ell}>1$, the expressions for prices are as follows:

$$
\begin{gathered}
p=\frac{\bar{\theta} q_{\ell}(\mu-1)}{(4 \mu-1)}, p_{\ell}=\frac{\lambda^{*} \bar{\theta} q_{\ell}(\mu-1)}{(4 \mu-1)} \\
p^{*}=\frac{2 \lambda^{*} \bar{\theta} q_{h}^{*}(\mu-1)}{(4 \mu-1)}, p_{h}^{*}=\frac{2 \bar{\theta} q_{h}^{*}(\mu-1)}{(4 \mu-1)}
\end{gathered}
$$

Equilibrium prices depend on qualities and on the primitive parameters $\lambda^{*}$ and $\bar{\theta}$. The quality $\mu$ is a measure of price competition as the ratio of prices is $p_{h}^{*} / p=p^{*} / p_{\ell}=2 \mu$.

A product is to be considered as being dumped if its export price to a particular country is less than a "normal value," standard used by the WTO, or less than a "fair value," standard used by the U.S. government. There are different ways of calculating a product's "normal" or "fair" value, two of which are considered here. A first definition of dumping considers the competing local price as a proxy for the normal value. Though this is characterized as the "lay" definition of dumping (Weinstein, 1992), the method has been used in theory (Vandenbussche and Wauthy, 2001) and applied in a number of cases, among others in Mexico (Niels, 2004). This is a definition of last resort, when other methods of calculations are either not possible or not leading to the desired outcome. In terms of our model, this method amounts to comparing $p_{\ell}$ to $p^{*}$, and $p$ to $p_{h}^{*}$. From (6) and (7), we obtain: 


$$
p_{\ell}<p^{*}, \quad p<p_{h}^{*}
$$

As it concerns goods of different qualities, a more careful approach involves also the use of hedonic prices, that is prices per unit of quality, which yields:

$$
\frac{p_{\ell}}{q_{\ell}}<\frac{p^{*}}{q_{h}^{*}}, \quad \frac{p}{q_{\ell}}<\frac{p_{h}^{*}}{q_{h}^{*}}
$$

It is clear from these inequalities that only the domestic firm charges a lower price abroad for its exports, both in terms of absolute and hedonic prices. The result is that, using this method, unilateral dumping by the low-quality firm is obtained.

The second and more standard definition of dumping, the one that is advanced by the WTO (see the WTO website), is when a company exports a product at a price lower than the price it normally charges on its own home market. In terms of our framework, this price comparison is based on (6) and (7) directly. As it concerns goods of the same quality, hedonic prices are not relevant, only absolute prices matter. Dumping by the foreign firm in the domestic market occurs if the international foreign currency price of high-quality exports is less than the local price: $p_{h}^{*}(1-t) / e<p^{*}$ or $(1-t) / e<\lambda^{*}$. Vice versa, dumping by the domestic firm aborad takes place if $e p_{\ell}\left(1-t^{*}\right)<p$ which implies $\lambda^{*}<1 /\left(1-t^{*}\right) e$. Hence, combining these two inequalities, reciprocal dumping arises if:

$$
\frac{(1-t)}{e}<\lambda^{*}<\frac{1}{\left(1-t^{*}\right) e}
$$

Condition (10) leads to a number of observations. First, dumping is a natural price strategy of firms in that it always takes place. Unilateral or reciprocal dumping arises when the crosscountry difference in incomes $\left(\lambda^{*}\right)$ falls within or outside a range of values defined by the exchange rate and the domestic and foreign tariff rates. This condition is different than the one obtained in the traditional treatments of dumping (Brander and Krugman, 1983; Weinstein, 1992). This is illustrated in Figure 2. There are three regions of parameters labelled $A, B$ and $C$. For a fixed exchange rate, if countries' difference in income is relatively small (region $A$ ), only unilateral dumping by the domestic firm occurs; reciprocal dumping arises when this parameter falls in region 
$B$, while unilateral dumping by the foreign firm is observed when the income difference is sufficiently large (region $C$ ).

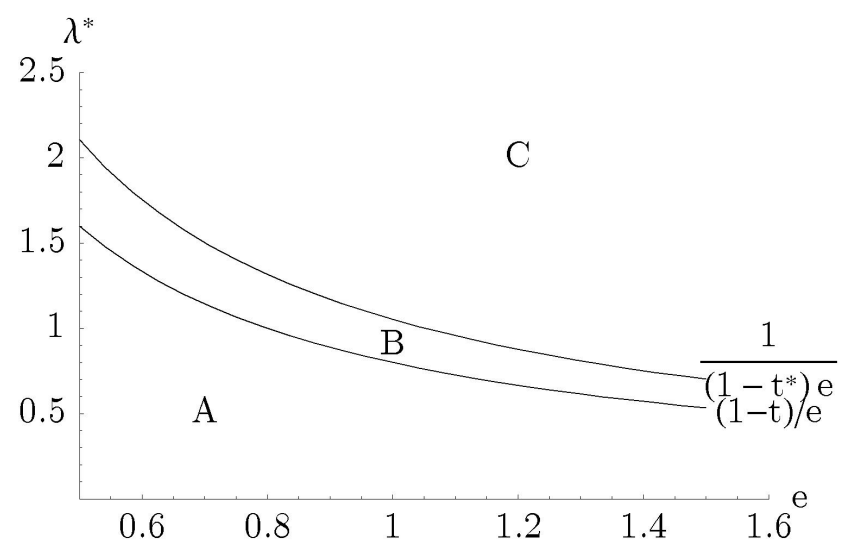

Figure 2: Unilateral and reciprocal dumping.

Second, the current nominal protection rates of developing and transition economies reveal high levels of tariff protection, from two to three times those of the U.S. or the European Union. Exceptions are the Baltic countries (see the World Bank website). Given this, a view that has been repeatedly put forward by various international organizations and governments is that high import tariffs of transition and developing economies are forcing foreign firms to dump in these markets (see for example, EC (2003)). Condition (10) examines the theoretical premises of such conjecture. Assuming $e=1$, it is clear that there is dumping by the foreign firm into the domestic market as long as $\lambda^{*}>1$ and the tariff rate is not instrumental. Dumping disappears only if $\lambda^{*}=1$ and $t=0$. Third, it is commonly believed that dumping arises because the arbitrage of goods through the re-shipment of exports is prohibited. This is not the case in our framework and it can be shown using (6) and (7) that when (10) holds, there is also no profit opportunity to export goods via parallel trade. When (10) does not hold, then unilateral dumping and arbitrage can coexist.

\section{Injury to the Local Industry}

We now examine firms' second-stage decisions: quality selection. In this stage firms take $(i)$ trade policies $\left(t, t^{*}\right)$ and $(i i)$ the exchange rate as given and anticipate the equilibrium prices of the continuation game obtained in (6) and (7). The domestic firm selects $q_{\ell}$ to maximize reduced-form profits: 


$$
\pi_{\ell}=\bar{\theta}\left(1+e\left(1-t^{*}\right) \lambda^{*} m^{*}\right) \frac{q_{\ell} q_{h}^{*}\left(q_{h}^{*}-q_{\ell}\right)}{\left(4 q_{h}^{*}-q_{\ell}\right)^{2}}-c \frac{q_{\ell}^{2}}{2}
$$

Likewise, the foreign firm chooses $q_{h}^{*}$ to maximize:

$$
\pi_{h}^{*}=4 \bar{\theta}\left[\frac{(1-t)}{e}+\lambda^{*} m^{*}\right] \frac{\left(q_{h}^{*}\right)^{2}\left(q_{h}^{*}-q_{\ell}\right)}{\left(4 q_{h}^{*}-q_{\ell}\right)^{2}}-c^{*} \frac{\left(q_{h}^{*}\right)^{2}}{2}
$$

Taking the first order conditions, we obtain the reaction functions in product quality. These best-response functions are represented in Figure 3. An equilibrium in qualities is given by the point at which the reaction functions intersect.

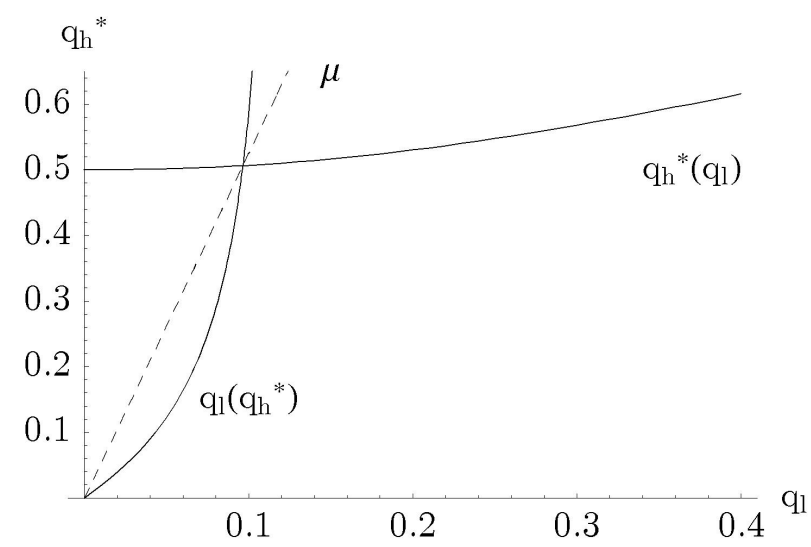

Figure 3: Equilibrium in qualities in the domestic market.

Recall that $\mu$ is the quality gap between firms' product qualities, $\mu=q_{h}^{*} / q_{\ell}>1$. The ray going through the origin and the point at which the best-response functions cross represents $\mu$, the measure of product differentiation in our model. The ratio of first-order conditions gives an implicit solution for $\mu$, as a function of relative costs in the same currency units, ad valorem tariffs and the other primitive parameters of the model:

$$
\mu=F\left(\stackrel{+}{c}, \overline{c^{*}}, \bar{e}, \bar{t}, \stackrel{+}{t^{*}}, \lambda^{*}, m^{*}\right)
$$

The signs reported in (13) give the response of the equilibrium quality gap to changes in the parameters of the model. 
Knowing $\mu$ and using the reaction functions in qualities, we can derive the market equilibrium of our model, that is, demands, qualities and, using (6) and (7), prices. For example demands are:

$$
\begin{aligned}
& D_{\ell}=\frac{\mu}{(4 \mu-1)}, D_{h}=\frac{2 \mu}{(4 \mu-1)} \\
& D_{\ell}^{*}=\frac{m^{*} \mu}{(4 \mu-1)}, D_{h}^{*}=\frac{2 m^{*} \mu}{(4 \mu-1)}
\end{aligned}
$$

A first characteristic of the market equilibrium is that it exhibits intra-industry trade in vertically differentiated goods. Models of vertical intra-industry trade date from the seminal contributions of Falvey (1981) and Shaked and Sutton (1983, 1984). Quality differences in our framework are measured in the latter tradition. The quantities $D_{\ell}^{*}$ and $D_{h}$ represent domestic exports of lowquality products and domestic imports of the high-quality variant respectively. The Grubel-Lloyd (GL) index in volume depends only on relative population sizes:

$$
G L=100\left\{1-\frac{\left|D_{\ell}^{*}-D_{h}\right|}{\left(D_{\ell}^{*}+D_{h}\right)}\right\}=100\left\{1-\frac{\left|m^{*}-2\right|}{\left(m^{*}+2\right)}\right\}
$$

When measured at international prices, the GL index in values depends on all parameters of the model. A second characteristic of the market equilibrium is the extent of import penetration in each market. Market shares of imports at home and abroad, respectively, are:

$$
\frac{D_{h}}{\left(D_{\ell}+D_{h}\right)}=\frac{2}{3}, \quad \frac{D_{\ell}^{*}}{\left(D_{\ell}^{*}+D_{h}^{*}\right)}=\frac{1}{3}
$$

Hence, the foreign firm supplies $2 / 3$ of home demand for this good whereas the home firm serves $1 / 3$ of foreign demand. Both market shares are large enough to justify genuine injury to each country's domestic industry.

\section{Exchange Rates}

Trends in nominal exchange rates indicate a tendency towards depreciation of transition economies' currencies and show exchange rate fluctuations that are often larger than the applied tariff rates. Nominal exchange rates in most Eastern European countries fell sharply during the second half of the 1990s but recently stabilized. Rates of depreciation versus the U.S. dollar were $25 \%$ for the 
Czech Koruna during that period and about 300\% for the new Russian Ruble in 1998 only. More recently, the Argentinean Peso experienced large depreciations as well.

As argued above, large fluctuations in currencies are a primary determinant of the occurrence of dumping. The evidence on the relationship of exchange rates variations and anti-dumping filings is however mixed. On the one hand, Feinberg (1989) finds that a U.S. dollar depreciation relative to a foreign currency has a significant positive effect on anti-dumping petitions in the U.S.. On the other hand, Knetter and Prusa (2003) obtain the opposite result that U.S. dollar appreciations positively affect petition filings in the U.S.. Niels (2004) finds a similar result for Mexico.

Empirical studies linking exchange rate fluctuations and petition filings indicate that the former raises/decreases the probability that domestic industries will be found to be suffering injury, regardless of whether imports are actually dumped or not. In contrast, our framework deals with both the likelihood of dumping and the extent of the injury. Regarding injury, the implications of exchange rate depreciations on qualities and profits can be seen in Figures 4 and ??. A depreciation of the domestic currency from $e_{1}$ to $e_{2}\left(e_{2}>e_{1}\right)$ shifts the best-response functions of the firms, which lowers the quality of imports and increases the quality of the domestic product ( $\mu$ decreases). As a result, market competitiveness increases.

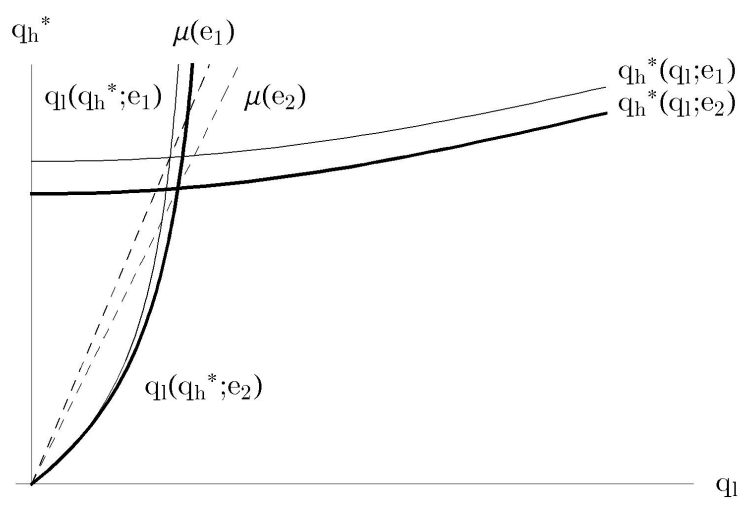

(a) Reaction functions, $\mu$ and the exchange rate

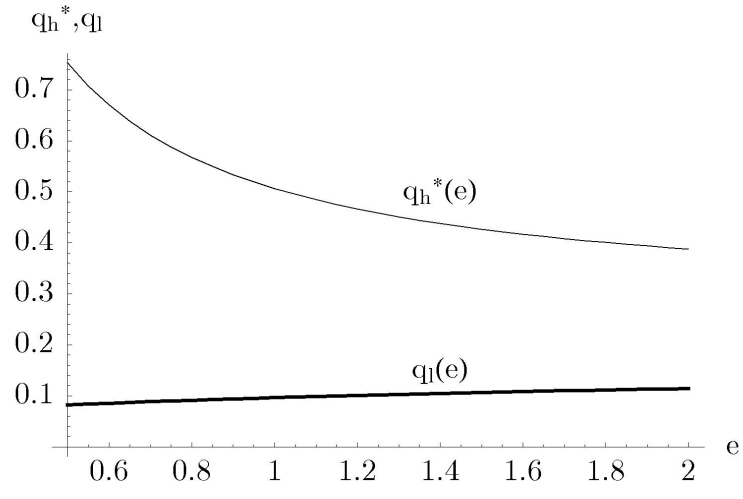

(b) Qualities and the exchange rate

Figure 4: Implications of an exchange rate depreciation on equilibrium qualities (home country).

Taking these two effects on profits into consideration, we can see that the profits of the local firm increase (Figure 5) as the exchange rate rises, thus inflicting no injury. If the market share of the domestic firm is the criterion to determine injury, then an increase in the exchange rate $e$ does not cause any further injury because market shares remain constant (see (17)). As a result, our analysis does not provide support to the positive relationship between exchange rate depreciations 
and anti-dumping filings.

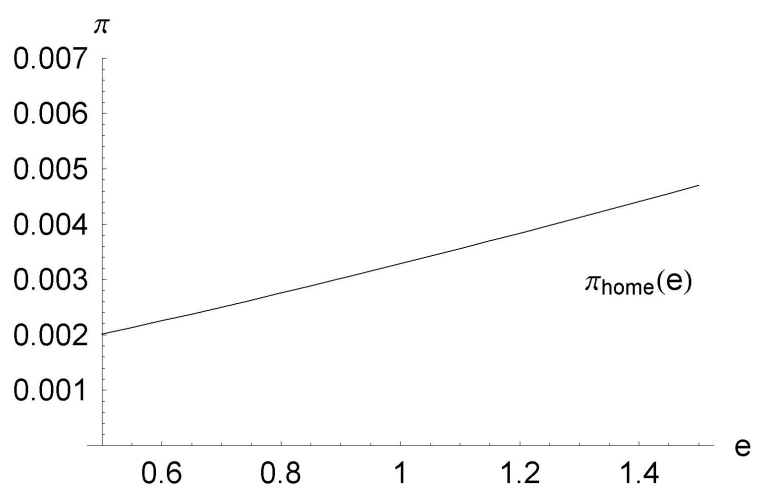

(a) Domestic firm

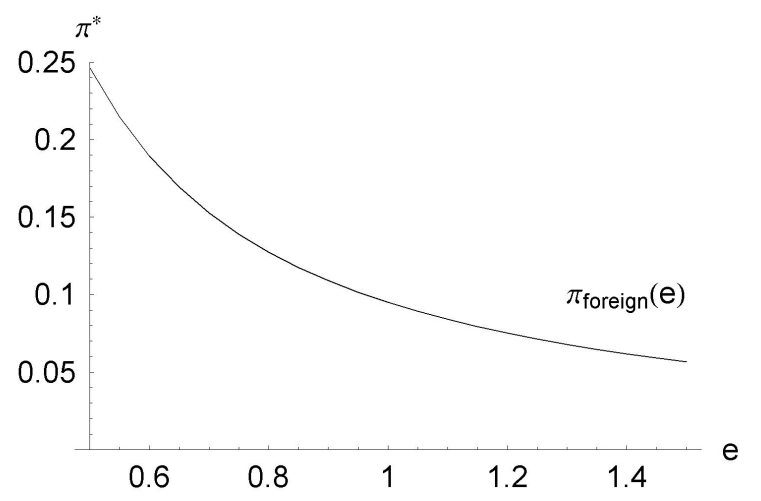

(b) Foreign firm

Figure 5: Profits of the firms and exchange rates.

The effects of an exchange rate depreciation on dumping are more clear-cut than on injury. For a fixed $\lambda^{*}$, Figure 2 reveals that an increase of the exchange rate increases the likelihood of dumping by the foreign firm and decreases the likelihood of dumping by the domestic firm abroad (vice versa for an appreciation). These results follow directly from (10) and the fact that exchange rate movements affect firms in opposite directions. Ceteris paribus, an increase in $e$ increases the gap between the international foreign currency price of high-quality and the local price abroad while it decreases the difference between the domestic currency price of low-quality exports and the domestic price.

\section{Conclusion}

In a simple model of vertical intra-industry trade, we have examined the incentives of oligopolistic exporting firms to undertake dumping. We have shown that dumping is a natural strategy when product quality matters because firms sell the same goods abroad and domestically at different prices in equilibrium. The definition of dumping is also instrumental in determining the occurrence and the nature of dumping. Based on a comparison of low-quality and high-quality prices, only unilateral dumping by the low-quality firm obtains. This measure is simple and often seen in realworld anti-dumping filings. By contrast, the standard WTO definition leads to either reciprocal or unilateral dumping depending on differences in incomes, the height of tariff protection and of exchange rate depreciations observed recently. For example, for fixed tariff rates and the exchange 
rate, if countries incomes are similar only unilateral dumping by the domestic low-quality firm occurs; reciprocal dumping arises when countries' difference in income is moderate; finally, unilateral dumping by the foreign high-quality firm is observed when the countries' income difference is sufficiently large.

Increases in the exchange rate raise the likelihood of dumping by the foreign high-quality firm and thus may lead to an increase in anti-dumping filings. However, we have found that a depreciation of the domestic currency leads to an increase in the quality produced in the domestic market and thus to an increase in the profits of the local firm. As a result, our model does not support the view that exchange rate depreciations have led to genuine injury and thus observed dumping claims in vertically differentiated markets of transition economies may be based on grounds different than injury. 


\section{Appendix: Glossary of Symbols}

$c, c^{*} \quad$ domestic, foreign quality development cost (in own currency)

$D_{\ell}, D_{\ell}^{*} \quad$ domestic, foreign demand for low quality

$D_{h}, D_{h}^{*} \quad$ domestic, foreign demand for high quality

$e \quad$ forward exchange rate (domestic price of foreign currency)

GL Grubel-Lloyd index

$m^{*} \quad$ population size abroad $\left(m^{*} \geq 1\right)$

$p \quad$ domestic currency price of low-quality consumption

$p^{*} \quad$ foreign currency price of high-quality consumption

$p_{\ell} \quad$ foreign currency price of low-quality exports

$p_{h}^{*} \quad$ domestic currency price of high-quality exports

$q_{\ell} \quad$ low quality (produced at home only)

$q_{h}^{*} \quad$ high quality (produced abroad only)

$t \quad$ domestic ad valorem tariff rate $(t>0)$

$t^{*} \quad$ foreign ad valorem tariff rate $\left(t^{*}>0\right)$

$\theta, \theta^{*} \quad$ domestic, foreign taste parameter

$\bar{\theta} \quad$ highest taste parameter observed at home

$\lambda \quad$ relative taste parameter $(\lambda>1)$

$\mu \quad$ quality gap $\left(q_{h}^{*} / q_{\ell}\right)$ 


\section{References}

[1] Aturupane, C., S. Djankov and B. Hoekman (1999), "Horizontal and Vertical Intra-Industry Trade between Eastern Europe and the European Union," Weltwirtschaftliches Archiv 135(1), $62-81$.

[2] Blonigen, B.A. and T.J. Prusa (2003), "Antidumping", in E.K. Choi and J. Harrigan (Eds.), Handbook of International Trade (Oxford, UK and Cambridge, MA: Blackwell Publishers), Chapter 9 .

[3] Boskin, M.F., E.R. Dulberger, R.J. Gordon, Z. Griliches and D.W. Jorgenson (1996), Toward a More Accurate Measure of the Cost of Living, Final Report to the Senate Finance Committee from the Advisory Commission (Washington DC: U.S. Government Printing Office).

[4] Brander, J.A. and P.R. Krugman (1983), "A 'Reciprocal Dumping' Model in International Trade," Journal of International Economics 15, 313-323.

[5] Eaton, B.C. and N. Schmitt (1994), "Flexible Manufacturing and Market Structure," American Economic Review, 84(4), 875-888.

[6] European Community-EC (2003), Twentieth Annual Report from the Commission to the European Parliament on the Community's Anti-Dumping and Anti-Subsidy and Safeguard Activities, Brussels (http://europa.eu.int/comm/trade/policy/dumping/reports.htm).

[7] Falvey, R. (1981), "Commercial Policy and Intra Industry Trade", Journal of International Economics, 11, 495-511.

[8] Feinberg, R.M. (1989), "Exchange Rates and Unfair Trade", Review of Economics and Statistics, 71, 704-707.

[9] Finger, J.M., F. Ng and S. Wangchuk (2000), "Antidumping as Safeguard Policy," Manuscript, World Bank, Washington DC.

[10] Greenaway, D., R. Hine, and C. Milner (1995), "Horizontal and Vertical Intra-Industry Trade: A Cross Industry Analysis for the UK, " Economic Journal 105, 1505-1518.

[11] Knetter, M.M. and T.J. Prusa (2003), "Macroeconomic Factors and Antidumping Filings: Evidence from Four Countries", Journal of International Economics, 61(1), 1-17. 
[12] Lankhuizen, M. (2000), "Shifts in Foreign Trade, Competitiveness and Growth Potential: from Baltics to 'Bal-Techs'?," Research Policy 29, 9-29.

[13] Moraga-González, J.L. and J.-M. Viaene (2004a), "Anti-dumping, Intra-industry Trade and Quality Reversals", Tinbergen Institute Discussion Paper.

[14] Moraga-González, J.L. and J.-M. Viaene (2004b), "Dumping in Developing and Transition Economics", Tinbergen Institute Discussion Paper.

[15] Motta, M., J.-F. Thisse and A. Cabrales (1997), "On the Persistence of Leadership or Leapfrogging in International Trade," International Economic Review 38(4), 809-824.

[16] Niels, G. T. (2004), A Political Economy Assessment of Antidumping Policy in Mexico, Ph. D. thesis, Erasmus University Rotterdam.

[17] Shaked, A. and J. Sutton (1983), "Natural Oligopolies", Econometrica 51(5), 1469-1483.

[18] Shaked, A. and J. Sutton (1984), "Natural Oligopolies and International Trade", in H. Kierzkowski (Ed.), Monopolistic Competition and International Trade, (Oxford: Oxford University Press).

[19] Tirole, J. (1988), The Theory of Industrial Organization, Cambridge, MA: MIT Press.

[20] Vandenbussche, H. and X. Wauthy (2001), "Inflicting Injury through Product Quality: How EU Anti-dumping Policy Disadvantages European Producers", European Journal of Political Economy, 17, 101-116.

[21] Weinstein, D.E. (1992), "Competition and Unilateral Dumping", Journal of International Economics 32, 379-387. 